\title{
Training for Student Teaching Fellows at Rowan University
}

\section{Dr. Linda M Head, Rowan University}

Associate Professor of Electrical and Computer Engineering

\section{Ms. Melanie Basantis, Rowan University}

Ms. Melanie Basantis (Director, Engineering Outreach Office) earned her MBA from Widener University and dual degrees in Industrial Engineering and Business Management from The Pennsylvania State University. Ms. Basantis spent 15 years in industry at the Boeing Company working as an Engineer on projects related to defense aircraft including the V-22 Osprey and $\mathrm{CH}-46$ and $\mathrm{CH}-47$ tandem rotor helicopters along with being a Composite Manger on the 757 and 767 commercial aircraft programs. Ms. Basantis has experience in the development and implementation of new and innovative technologies in the manufacturing processes associated with revolutionary, new assembly methods and concepts for aircraft application. She is experienced in the utilization of lean manufacturing, total quality management, and ISO concepts and specifications in the implementation of these processes. As Engineering Outreach Director, Ms. Basantis collaborates with industry on initiatives that include, but not limited to professionalism, internship experience, job placement, student development and enrichment, as well as concentrated faculty research. Ms. Basantis provides leadership to The College of Engineering's STEM initiatives and has done so for the past 10 years. Middle and High school camps and field experiences are held under her guidance and expertise.

\section{Dr. Steven H Chin P.E., Rowan University \\ Dr. Bernard Pietrucha, Rowan University}

\section{Bernard M. Pietrucha}

Instructor Department of Electrical and Computer Engineering College of Engineering Rowan University Education: B.S., Electrical Engineering, Newark College of Engineering (NJIT); M.S., Electrical Engineering, Newark College of Engineering (NJIT); Ph.D., Electrical Engineering, Rutgers University

Dr. Pietrucha has taught undergraduate courses in Electrical and Computer Engineering and Freshman and Sophomore Clinic in addition to cross-disciplinary courses with Mechanical Engineering at Rowan University. Prior to joining Rowan in 2001, he was an Adjunct Professor of electrical Engineering at Newark College of Engineering (NJIT) for 16 years. Dr. Pietrucha's industrial experience includes employment at AT\&T, Bell Labs, and Lucent Technologies, where he worked in communications satellites, semiconductor device development and qualification, and cellular telephone base station development and manufacturing. He also worked for the RCA Solid State Division as a semiconductor product engineer. He served as the General Chair of the 2004 IEEE International Reliability Physics Symposium and is a former editor for reliability for the IEEE Transactions on Semiconductor Manufacturing. 


\title{
Training for Student Teaching Fellows at Rowan University
}

\begin{abstract}
Rowan University has recently been awarded Research Institution status. With this new designation there is an increasing emphasis on graduate education and on recruiting talented graduate students from both our undergraduate programs and from schools in our region. In order to promote recruitment and enhance retention, the university has developed a Teaching Fellows Program that provides our graduate students with funding for four semesters as they work toward a Master's Degree in their chosen major. With this opportunity in mind, the College of Engineering Dean's Office and the four department Chairpersons formed a committee to develop a summer training program that prepares the Teaching Fellows for the classroom experience. The program has four stages: 1) Orientation, 2) Instruction, 3) Classroom Immersion, and 4) Individual Practice. In this paper each stage is described in detail. This intensive training program with its novel use of classroom experience in summer programs has provided the Teaching Fellows the opportunity to gain the confidence and skills to succeed in their Fellowship requirements. A full description of the program and assessment data and analysis are presented.
\end{abstract}

\section{Introduction}

At public 4-year institutions Teaching Assistants make up approximately 15\% of instructors, while at research intensive schools this number is often as high as $45 \%$ with the Teaching Assistants concentrated in the lower division courses. Effective training of Teaching Assistants is crucial for two reasons. First, since instructor contact is known to be a strong predictor of success for undergraduate students, the Teaching Assistants can exert a significant impact on retention and future recruitment. Second, a new Teaching Assistant will transition in a single semester from undergraduate student to a combination of researcher, classroom student and instructor. The ability to successfully negotiate these responsibilities is key to their own academic success making appropriate mentoring and training crucial ${ }^{1}$.

In the College of Engineering each of our four departments was assigned funding for three Teaching Assistants that are designated Fellows. The Teaching Fellows (TFs) not only take classes, work on their thesis research and assist with undergraduate laboratories, they also have the opportunity to gain direct classroom experience as instructor of record for a freshman or sophomore course. With these opportunities in mind, the College of Engineering Dean's Office and the four department Chairpersons formed a committee to develop a summer training program that prepares the TFs for the teaching experience.

Since TFs are assigned to a wide variety of different teaching environments a generalist approach to the overall training and a close collaboration with faculty mentors is a priority. It is important that the TFs are able to enhance their professional development as researchers while also learning to communicate effectively in the classroom ${ }^{2}$.

The program has four stages: 1) Orientation, 2) Instruction, 3) Classroom Immersion, and 4) Individual Practice. In this paper each stage is described in detail. After a day of introductions 
and welcome to the program by administrators and mentors, instruction in classroom and laboratory techniques was provided by master teachers from the engineering program. Next, six weeks of summer programs for local middle school and high school students provided the context for an intense classroom experience for the TFs. All TFs prepared lectures and projects that they presented to the middle and high school students in our summer outreach programs. These programs ranged from a day with middle school students to a week-long program for high school juniors and seniors with interest and background in engineering. Following their classroom experience, each TF was given their teaching assignment for the fall semester and had the opportunity to prepare and receive feedback on an actual lecture or lab assignment. This intensive training program with its novel use of classroom experience in summer programs has provided the TFs the confidence and skills to succeed in completing their Fellowship requirements. A full description of the program and assessment data and analysis are presented.

Program Goals \& Objectives

GOAL I: Introduce Program Benefits and Responsibilities to new Teaching Fellows

Obj 1: Provide College Dean's Office and Individual Departments with the opportunity to communicate general expectations

Obj 2: Describe Fellowship benefits and responsibilities

Obj 3: Define workload requirements and limits

Obj 4: Provide Teaching Fellows with opportunity to resolve all administrative questions

GOAL II: Communicate instructional strategies and requirements

Obj 1: Instruct Teaching Fellows in approved pedagogy

Obj 2: Provide a forum for hands-on training and practice

Obj 3: Emphasize best practice teaching techniques

GOAL III: Enhance Professional development opportunities

Obj 1: Create an open mentoring environment between Fellows and Faculty

Obj 2: Encourage self-efficacy and self-confidence of TF's in public-presentation environment

Obj 3: Provide the opportunity for TFs to review basic knowledge

Obj 4: Reinforce critical thinking skills through public dialog

\section{Methods}

There are eight TFs who participated in the training program, six men and two women. They were all new BS graduates from this university in one of the four following disciplines: Chemical Engineering, Civil Engineering, Electrical and Computer Engineering, Mechanical Engineering. None of these eight Master's students had any prior teaching experience at the post-secondary level. 
The Engineering College has a hands-on / minds-on tradition of student involvement in learning. The training that has been developed for the new graduate student TFs continues and expands this tradition. All training activities for the TFs rely primarily on practice working with either administrative or faculty mentors to acquire and improv their teaching skills. Beginning the summer 2013 semester with interactive instruction from Master Teachers and ending with preparation of their own classroom content, the TFs were well prepared to enter the classroom in Fall 2013.

\section{Training Program}

Our goals and objectives will constitute the organizing principle for the description of the Teaching Fellow Training Program.

\section{GOAL I: Introduce Program Benefits and Responsibilities to new Teaching Fellows}

The initial event for the Teaching Fellow Training was an afternoon introductory session. This session was attended by representatives of the Dean's Office and the Office of the Provost, the Chairs of the four Engineering Programs and the Fellows. Each representative spoke about the program from their individual perspective. The Provost focused on the transition facing the TF's as they moved from undergraduate student to instructor in the laboratory and classroom and role model as graduate student and researcher. His encouragement and enthusiastic welcome began the summer semester Training Program. Dean's office staff next introduced the Training Program schedule shown below in Table 1.

Table 1: Teaching Fellow Training Program Schedule, Summer 2013

\begin{tabular}{|l|l|l|}
\hline \multicolumn{1}{|c|}{ DATE/TIME } & \multicolumn{1}{|c|}{ TOPIC } & \multicolumn{1}{c|}{ PRESENTER } \\
\hline MAY 29 / 11:30AM & Orientation & $\begin{array}{l}\text { Administrators \& } \\
\text { Staff }\end{array}$ \\
\hline June 4 / 1:00pm to 2:30pm & Presentation on Classroom Teaching & Faculty Member \\
\hline June 11 / 10:30am to 12:00pm & Presentation on Laboratory Teaching & Faculty Member \\
\hline June 18 / 10:00am to 1:00pm & $\begin{array}{l}\text { STEM Teaching Practicum Preparation } \\
\text { Session }\end{array}$ & Dean's Office Staff \\
\hline June 25 thru July 25 & STEM Teaching Practicum & Teaching Fellows \\
\hline $\begin{array}{l}\text { August 7, 14, 21, 28 / 11:00am to } \\
\text { 1:00pm }\end{array}$ & Peer Assessment of Teaching & Teaching Fellows \\
\hline
\end{tabular}

Obj 1: Provide College Dean's Office and Individual Departments with the opportunity to communicate general expectations

The expectations for both the summer training and the fall and spring semester teaching assignments were described. The TFs are required to attend all training events during the summer semester. All but one of the 8 TFs were attending classes and working on research simultaneously and all training sessions were scheduled such that there was no conflict with other responsibilities. Each department chair described the type of teaching assignment (classroom, laboratory or combination) that a TF could expect in their department. 
Obj 2: Describe Fellowship benefits and responsibilities

The primary benefit of the training program was to transition the TF mindset from student to instructor. Instead of simply absorbing the material, they were now responsible for effective preparation and dissemination of it. Becoming the leader in a classroom is typical of any profession, adhering to the standard learning curve experience. Growing pains of entering the undergraduate classroom were minimized by providing a forum in which they could practice and hone their pedagogical skills, along with a venue for personalized evaluation and constructive assessment.

Obj 3: Define workload requirements and limits

Financial arrangements for tuition waiver and monthly stipend were explained. TF's were also made aware of the academic and teaching requirements for maintaining the appointment as a Fellow.

Obj 4: Provide Fellows with opportunity to resolve all administrative questions

A question and answer session ended the Introduction

GOAL II: Communicate instructional strategies and requirements

Obj 1: Instruct Fellows in approved pedagogy

Initial training sessions focused on teaching strategies and techniques. One current and one former faculty member were engaged to provide the TFs with information about teaching from two separate perspectives. The format was a one and one half hour lecture/discussion with a teaching mentor and all TFs attending. First, the classroom perspective was discussed with an emphasis on teaching and learning styles. The TFs were made aware of the need for personal perspective and the needs of students as individual learners. The second session was focused on a laboratory perspective with an emphasis on inquiry-based learning strategies. These two sessions aided in the preparation for the third phase of training, immersion in classroom and laboratory practice.

Obj 2: Provide forum for hands-on training and practice

Summer programs for middle school and high school students have become a staple of most universities' outreach for recruitment and service to their local community. These programs present an excellent opportunity for the TFs to gain experience in two important aspects of the educational environment, content preparation and classroom/ lab delivery. Content preparation requires that the TF: a) familiarize with the topic, b) prepare presentation materials such as Powerpoint files, c) identify laboratory resources and supplies for the lesson, d) create activity descriptions and instructions, and e) assure that all preparations are targeted to the background and skills level of the students. Classroom/laboratory delivery requires that the TF: a) present in a professional manner, b) maintain a classroom environment that is conducive to learning for all 
students, c) monitor student attention and apparent understanding of the course content, d) assist student groups with activities, and e) assess learning and plan for future sessions.

While summer programs for middle and high school students typically do not have the same rigorous treatment of academic content that is found in a college course, the learning environment can mimic many of the same situations encountered. For this reason the TFs were assigned to engage in one or more sessions of the outreach programs offered to the middle and high school students in the local community.

Obj 3: Emphasize best practice teaching techniques

Participation in the outreach programs began with instruction and mentoring by a faculty member who has been active in these programs for many years. A half-day session was devoted to discussion of content preparation and a demonstration of a typical program activity. The TFs role-played the students they would be teaching when they supervise a session during the outreach program to which they were assigned.

Each TF met with a Faculty mentor(s) to become familiar with two or three hands-on STEM projects that would be their responsibility through the summer programs. Faculty provided a detailed description of the project, lab instruction, relevant engineering theory and principles, and teaching tips. Since the modules were co-taught by two TFs, after the faculty session, the TFs were able to review, discuss and practice module delivery. Some of the programs are offered multiple times during the summer giving the TFs the opportunity to refine their project and delivery. Throughout the summer mentoring continued by the project faculty and the supervising mentor who worked with the TF's at the preparation phase. Each of the TFs was encouraged to engage in self-assessment of their performance using the form shown in Appendix A as a guide.

\section{GOAL III: Enhance Professional development opportunities}

In the final phase of the training program preparations began for the coming fall semester when the TFs would begin their actual teaching assignment. At this stage all teaching assignments had been completed and the TF's knew either the laboratory they would be supervising in collaboration with a faculty member assigned to the lecture portion of the class or the actual course they would be assigned to teach.

Obj 1: Create open mentoring environment between Fellows and Faculty

Each TF met with their Department Chair to discuss their assignment and review department requirements, procedures, rules and protocol. With the collaborating faculty member they discussed, in the context of ABET requirements and department culture, syllabus preparation and assessment requirements. The integration of the TF's into the department culture is important to their success as instructors and learners as well as to the success of the undergraduates that they teach.

Obj 2: Encourage self-efficacy and self-confidence of TF's in public-presentation environment 
Obj 3: Provide opportunity for Fellows to review basic knowledge

Obj 4: Reinforce critical thinking skills through public dialog

The final month before classes began in Fall 2013 was devoted to peer evaluation of lecture techniques and content clarity. Each week two of the TFs prepared a ten to fifteen minute lecture on a topic from their discipline and presented to their peers. In an informal discussion environment the presenting TF was given feedback on their delivery, clarity, comprehensive coverage of the topic and the appropriateness of the presentation for an undergraduate audience.

\section{Assessment}

To date our assessment consists of the impressions of the TF's after the completion of their first semester of teaching. All eight responded to a series of statements and questions that related to the goals of the training program and to the specific activities that comprised the program. Table 2 shows individual and average responses to the Statements.

Table 2

\begin{tabular}{|c|l|l|l|l|l|l|l|l|l|c|}
\hline & $\begin{array}{l}\text { STATEMENTS: RESPONSE ON A SCALE } \\
\text { OF 1 (NO AGREEMENT) TO 5 } \\
\text { (COMPLETE AGREEMENT) }\end{array}$ & \multicolumn{7}{|l|}{ INDIVIDUAL RESPONSES } & \multicolumn{2}{|c|}{ AVERAGE } \\
\hline 1 & $\begin{array}{l}\text { The Teaching Fellow (TF) Orientation "Day of } \\
\text { Introduction" was adequate to familiarize the } \\
\text { new TF's with the details of the fellowship. }\end{array}$ & 4 & 4 & 4 & 4 & 4 & 4 & 5 & 4 & 4.125 \\
\hline 2 & $\begin{array}{l}\text { The TF Orientation "Day of Introduction" was } \\
\text { adequate to familiarize the new TF's with the } \\
\text { details of the summer training. }\end{array}$ & 4 & 4 & 5 & 4 & 4 & 3 & 4 & 5 & 4.125 \\
\hline 3 & $\begin{array}{l}\text { I received adequate instruction and mentoring } \\
\text { for supervising my projects for the summer } \\
\text { programs. }\end{array}$ & 4 & 3 & 5 & 5 & 5 & 3 & 3 & 4 & 4 \\
\hline 4 & $\begin{array}{l}\text { There was adequate time to prepare my } \\
\text { projects for the summer programs. }\end{array}$ & 4 & 5 & 5 & 4 & 5 & 3 & 4 & 4 & 4.25 \\
\hline 5 & $\begin{array}{l}\text { Participation in the summer programs for } \\
\text { MIDDLE SCHOOL students was helpful to me } \\
\text { in learning to function successfully as a } \\
\text { Teaching Fellow. }\end{array}$ & 3 & 4 & 4 & 2 & 3 & 2 & 4 & 4 & 3.25 \\
\hline 6 & $\begin{array}{l}\text { Participation in the summer program for HIGH } \\
\text { SCHOOL students was helpful to me in } \\
\text { learning to function successfully as a Teaching } \\
\text { Fellow. }\end{array}$ & 4 & 4 & 5 & 2 & 3 & 3 & 5 & 4 & 3.75 \\
\hline 7 & $\begin{array}{l}\text { The peer assessment of lectures was helpful in } \\
\text { preparing for my semester TF assignment. }\end{array}$ & 3 & 5 & 5 & 3 & 4 & 5 & 3 & 5 & 4.125 \\
\hline
\end{tabular}

Support was strong for the procedures used to give access to information (statements 1 and 2). Additionally, the new TFs felt respected and supported by the mentors assigned to the program (statements 3 and 4). Statement 4 responses show agreement that peer assessment of lecture presentations had a positive effect on the content and self-confidence of the TFs in their first teaching assignments.

Support for the middle and high school teaching experience as a useful training ground for undergraduate teaching was rated neutral. Further comment requires reference to the question section of the evaluation. 


\begin{tabular}{|c|c|c|c|c|c|}
\hline QUESTIONS & \multicolumn{5}{|c|}{ INDIVIDUAL RESPONSES } \\
\hline $\begin{array}{l}\text { 1. What did you } \\
\text { learn from the } \\
\text { presentations of Dr. } \\
\text { Farrell and/or Dr. } \\
\text { Mandayam that has } \\
\text { been helpful in your } \\
\text { TF assignment } \\
\text { during the Fall } 2013 \\
\text { semester? }\end{array}$ & $\begin{array}{l}\text { I think that the most } \\
\text { important thing that I } \\
\text { learned from Dr. } \\
\text { Mandayam's } \\
\text { presentation was } \\
\text { that, by the end of } \\
\text { each lesson, students } \\
\text { should understand } \\
\text { one major concept } \\
\text { that related to the } \\
\text { lesson. For this } \\
\text { reason, I have tried } \\
\text { to make sure that my } \\
\text { lessons and labs do } \\
\text { not focus on too } \\
\text { many little things, as } \\
\text { long as the } 1 \text { or } 2 \\
\text { major concepts have } \\
\text { been discussed } \\
\text { correctly. }\end{array}$ & $\begin{array}{l}\text { I found Dr. Farrell's } \\
\text { presentation to be } \\
\text { helpful in } \\
\text { understanding } \\
\text { different learning } \\
\text { styles. I approached } \\
\text { students with } \\
\text { different styles of } \\
\text { teaching in order to } \\
\text { convey a certain } \\
\text { message. I didn't } \\
\text { particularly find Dr. } \\
\text { Mandayam's } \\
\text { presentation helpful } \\
\text { nor do I remember it. }\end{array}$ & $\begin{array}{l}\text { Dr. Farrell: The } \\
\text { different styles of } \\
\text { learning. } \\
\text { Dr. Mandayam: } \\
\text { Successful ways to } \\
\text { guide students } \\
\text { through a lab. }\end{array}$ & $\begin{array}{l}\text { It was useful to } \\
\text { consider the different } \\
\text { learning styles of } \\
\text { students when } \\
\text { preparing my } \\
\text { lectures. }\end{array}$ & $\begin{array}{l}\text { From Dr. Farrell, I } \\
\text { recalled her } \\
\text { discussion with us } \\
\text { about the different } \\
\text { learning styles of } \\
\text { students. Because } \\
\text { most of my teaching } \\
\text { was within a } \\
\text { laboratory setting, I } \\
\text { tried to appeal to all } \\
\text { of the learning styles } \\
\text { of students. I came } \\
\text { up with handouts for } \\
\text { students who like to } \\
\text { read first and act } \\
\text { second, and I } \\
\text { verbally walked } \\
\text { through the } \\
\text { experiments for the } \\
\text { auditory learners. } \\
\text { Finally, since these } \\
\text { were lab classes, } \\
\text { those who learn by } \\
\text { actively participating } \\
\text { had opportunities for } \\
\text { hands on learning as } \\
\text { well. }\end{array}$ \\
\hline $\begin{array}{l}\text { 2. Name a topic } \\
\text { NOT addressed by } \\
\text { Drs. Farrell and } \\
\text { Mandayam during } \\
\text { TF Orientation that } \\
\text { would have been } \\
\text { helpful for your first } \\
\text { semester. }\end{array}$ & $\begin{array}{l}\text { I felt adequately } \\
\text { prepared to teach this } \\
\text { semester. However, } \\
\text { when it came to } \\
\text { grading, I was not } \\
\text { sure if I was being } \\
\text { too lenient or not. A } \\
\text { discussion on } \\
\text { grading might be } \\
\text { something to } \\
\text { consider for the next } \\
\text { group of teaching } \\
\text { fellows. }\end{array}$ & $\begin{array}{l}\text { The training sessions } \\
\text { should be more } \\
\text { hands on and giving } \\
\text { examples of } \\
\text { situations would be } \\
\text { great! }\end{array}$ & $\begin{array}{l}\text { Dr. Farrell: More } \\
\text { time could be spent } \\
\text { on tips for dealing } \\
\text { with the different } \\
\text { learning styles. } \\
\text { Dr. Mandayam: } \\
\text { More time discussing } \\
\text { how to keep students } \\
\text { engaged in lab. }\end{array}$ & Grading & $\begin{array}{l}\text { None. For me, the } \\
\text { things that weren't } \\
\text { included in the } \\
\text { orientation were best } \\
\text { learned by teaching. }\end{array}$ \\
\hline $\begin{array}{l}\text { 3. What } \\
\text { addition/subtraction } \\
\text { do you suggest to } \\
\text { improve the TF } \\
\text { Orientation } \\
\text { experience? }\end{array}$ & $\begin{array}{l}\text { If there are any } \\
\text { specific tips or } \\
\text { methods of teaching } \\
\text { recommended for } \\
\text { those of us who are } \\
\text { teaching in a } \\
\text { laboratory setting, } \\
\text { that would be a topic } \\
\text { I believe would be } \\
\text { useful in future } \\
\text { orientations. }\end{array}$ & $\begin{array}{l}\text { More time for } \\
\text { lectures by both Dr. } \\
\text { Farrell and Dr. } \\
\text { Mandayam. }\end{array}$ & $\begin{array}{l}\text { Gudience (sic) for } \\
\text { grading quizes and } \\
\text { lab reports } \\
\text { More practice on } \\
\text { how to create lab/ } \\
\text { lecture plans }\end{array}$ & $\begin{array}{l}\text { I don't think the } \\
\text { summer program } \\
\text { was particularly } \\
\text { useful for learning to } \\
\text { teach because the } \\
\text { environment was } \\
\text { much different. } \\
\text { However, I } \\
\text { understand that we } \\
\text { were getting paid for } \\
\text { the summer, so it } \\
\text { makes sense that we } \\
\text { should have been } \\
\text { contributing to the } \\
\text { summer programs. I } \\
\text { may be a little biased } \\
\text { because I had to } \\
\text { make a } 2 \text { hour drive } \\
\text { each way for each of } \\
\text { these hour and a half } \\
\text { visits. }\end{array}$ & $\begin{array}{l}\text { I don't believe that } \\
\text { the middle school } \\
\text { teaching helped the } \\
\text { teaching fellows } \\
\text { prepare for the } \\
\text { educating of college } \\
\text { courses. It was } \\
\text { mostly just the } \\
\text { teaching fellows } \\
\text { playing with the } \\
\text { students more than } \\
\text { actually teaching. } \\
\text { The high school } \\
\text { teaching helped a bit } \\
\text { more, but again it } \\
\text { was more of a } \\
\text { summer camp than } \\
\text { actual teaching. The } \\
\text { peer evaluations are } \\
\text { what helped most of } \\
\text { us in our teaching } \\
\text { endeavors, so I think } \\
\text { that there should be } \\
\text { more of these spaced } \\
\text { out. The rest of the } \\
\text { orientation felt like }\end{array}$ \\
\hline
\end{tabular}




\begin{tabular}{|c|c|c|c|c|c|}
\hline & & & & & $\begin{array}{l}\text { busy work more than } \\
\text { anything else. }\end{array}$ \\
\hline $\begin{array}{l}\text { 4. What was the } \\
\text { most valuable part of } \\
\text { the TF Orientation } \\
\text { experience? }\end{array}$ & $\begin{array}{l}\text { I appreciated how } \\
\text { candid the faculty } \\
\text { were with us during } \\
\text { orientation, and how } \\
\text { they were willing to } \\
\text { share their first } \\
\text { teaching experiences } \\
\text { with us. }\end{array}$ & $\begin{array}{l}\text { I enjoyed the peer } \\
\text { assessment of } \\
\text { lectures because that } \\
\text { was the most } \\
\text { informative way to } \\
\text { address and discuss } \\
\text { how I teach. I } \\
\text { received a lot of tips } \\
\text { and such. }\end{array}$ & $\begin{array}{l}\text { The workshops were } \\
\text { fun, and they helped } \\
\text { gain some } \\
\text { experience working } \\
\text { with a large group. }\end{array}$ & $\begin{array}{l}\text { The orientation } \\
\text { lectures by Dr } \\
\text { Mandayam and Dr } \\
\text { Farrell were useful, } \\
\text { but I think the best } \\
\text { way to learn how to } \\
\text { teach is to actually } \\
\text { do it. }\end{array}$ & $\begin{array}{l}\text { The peer evaluation } \\
\text { teaching sessions. } \\
\text { The practice session } \\
\text { for lecturing }\end{array}$ \\
\hline $\begin{array}{l}\text { 5. Any other } \\
\text { comments? }\end{array}$ & $\begin{array}{l}\text { I feel that the type of } \\
\text { work performed by } \\
\text { each teaching fellow } \\
\text { differs greatly, so } \\
\text { some of these } \\
\text { general lessons that } \\
\text { can be applied in any } \\
\text { situation were a good } \\
\text { idea. }\end{array}$ & $\begin{array}{l}\text { We are graduate } \\
\text { students going to X } \\
\text { to get our Master's } \\
\text { degree in ECE. I } \\
\text { understand that part } \\
\text { of being a graduate } \\
\text { students is also being } \\
\text { a TF, but teaching } \\
\text { middle and high } \\
\text { students is not } \\
\text { helping us in any } \\
\text { way. }\end{array}$ & & & \\
\hline
\end{tabular}

When considering the responses that addressed the middle and high school outreach programs in conjunction with the neutral scores from the statement portion of the evaluation, it is evident that a clearer justification for the relationship of these programs to teaching practice must be developed. Most TFs were positively disposed to receiving information (questions 1 and 2) and several commented on the value of the peer assessment but only one TF commented on the useful aspect of the outreach programs as teaching experience/practice.

Assessment analysis recommends additional communication regarding Goal I, Objective 2: Fellowship benefits and responsibilities. At orientation, TFs need to be informed that transitioning from student to instructor is a building process. Summer training programs give them the foundation on which to do so at a very elementary level. As recent undergraduates, TFs need to be educated on the expectations of middle and high school instructors. A brief training session, collaborating with the College of Education has been suggested for future integration.

As a future assessment initiative, included in the workshop participants' surveys, will be an evaluation metric of each TF's session and an appraisal, from the workshop participant's perspective. A question regarding both theoretical impact in addition to the TF's pedagogy will be addressed. It will be advised that the Faculty supervisor who meets individually with each TF, will provide constructive insight from these middle and high school workshop surveys.

Further assessment will include feedback from students and interviews with department chairs and faculty who observed and worked with the TF's.

\section{Conclusions}

As more graduate students are admitted to new and expanded programs the need for Orientation and Training programs will clearly grow in size and scope. Maintaining a quality undergraduate experience while providing an avenue for financial support and teaching experience for graduate students is a serious challenge. The training described in this paper provides a balanced set of programmatic activities encompassing a) information transmission, b) instruction, c) active 
experience in the classroom, d) opportunity for feedback and e) significant faculty mentoring. Improvements for the next entering graduate class will include all assessment results. One particularly important future plan is to consider an ongoing seminar for the TFs to support learning throughout their first semester ${ }^{3}$.

\section{References}

1. Complicity or Multiplicity? Defining Boundaries for Graduate Teaching Assistant Success, Karen Dunn-Haley, Anne Zanzucchi, New Directions for Teaching and Learning Volume 2012, Issue 131, Article first published online: 18 SEP 2012

2. Graduate Teaching Assistant Training That Fosters Student-Centered Instruction and Professional Development Pentecost, Thomas C; Langdon, Laurie S; Asirvatham, Margaret; Robus, Hannah; Parson, Robert.Journal of College Science Teaching 41.6 (Jul/Aug 2012): 68-75.

3. Offering More Than "Here Is the Textbook": Teaching Assistants' Perspectives on Introductory Science Courses Dotger, Sharon, Journal of College Science Teaching 39.3 (Jan/Feb 2010): 71-76. 


\section{APPENDIX A}

Proposed Self-Evaluation for Teaching Fellows - Summer STEM Programs

Please rate yourself on the 1 to 5 scale, 1 being "Barely Adequate" and 5 "Outstanding"

Preparedness

Familiarity with demo materials

$\begin{array}{lllll}1 & 2 & 3 & 4 & 5\end{array}$

Ability to answer participant questions

$\begin{array}{lllll}1 & 2 & 3 & 4 & 5\end{array}$

Appropriate attire

$\begin{array}{lllll}1 & 2 & 3 & 4 & 5\end{array}$

Instructional Practices

Effectively communicated with students

$\begin{array}{lllll}1 & 2 & 3 & 4 & 5\end{array}$

Explained content clearly

$\begin{array}{lllll}1 & 2 & 3 & 4 & 5\end{array}$

Spoke to the group clearly

$\begin{array}{lllll}1 & 2 & 3 & 4 & 5\end{array}$

Wrote on the board neatly and readably

$\begin{array}{lllll}1 & 2 & 3 & 4 & 5\end{array}$

Fair and consistent with all students

$\begin{array}{lllll}1 & 2 & 3 & 4 & 5\end{array}$

Engagement with Participants

Engaged participants with the material

$\begin{array}{lllll}1 & 2 & 3 & 4 & 5\end{array}$

Established working relationship with participants

$\begin{array}{lllll}1 & 2 & 3 & 4 & 5\end{array}$

Treated participants with respect

$\begin{array}{lllll}1 & 2 & 3 & 4 & 5\end{array}$

Motivated uninterested participants

$\begin{array}{lllll}1 & 2 & 3 & 4 & 5\end{array}$

Offered feedback to participants

$\begin{array}{lllll}1 & 2 & 3 & 4 & 5\end{array}$

Overcame cultural/language conflicts

$\begin{array}{lllll}1 & 2 & 3 & 4 & 5\end{array}$

Motivated participants to be creative

$\begin{array}{lllll}1 & 2 & 3 & 4 & 5\end{array}$

Facilitated discussion within teams

$\begin{array}{lllll}1 & 2 & 3 & 4 & 5\end{array}$

Showed enthusiasm with participants

$\begin{array}{lllll}1 & 2 & 3 & 4 & 5\end{array}$

Acted as a positive role model

$\begin{array}{lllll}1 & 2 & 3 & 4 & 5\end{array}$

\section{Classroom Management}

Managed disruptive behavior

$\begin{array}{lllll}1 & 2 & 3 & 4 & 5\end{array}$

Maintained authority

$\begin{array}{lllll}1 & 2 & 3 & 4 & 5\end{array}$

Avoided offending participants (didn't “talk down”)

$\begin{array}{lllll}1 & 2 & 3 & 4 & 5\end{array}$

